\title{
Moral values and methods of moral education at Samin community
}

\author{
Alil Rinenggo ${ }^{1}$, Eny Kusdarini ${ }^{2}$
}

1,2 Pancasila and Citizenship Education Study Program, Universitas Negeri Yogyakarta, Indonesia

\section{ABSTRACT}

The research aims to describe the Samin community's moral values, the moral education methods applied by elder Samin, and the obstacles to moral education. The study uses a qualitative approach to ethnographic research. Data collection techniques are through in-depth interviews, participatory observation, and documentation. Data validated by source triangulation and technique triangulation. The research subjects were determined purposively, including Samin elders, the Samin community, and Klopoduwur Village Officials. The results showed that the Samin community had moral values of ancestral heritage categorized into three types: Panca Sesanti, Panca Wewaler, and Panca Peniten. The method applied is through oral traditions, wise words, habituation, role models, question and answer. Obstacles in moral education are negative stigma from other communities

Article History:

$\begin{array}{ll}\text { Submitted } & : \text { 21-09-2020 } \\ \text { Revised } & : 07-01-2021 \\ \text { Accepted } & : 01-02-2021\end{array}$

Keywords:

Samin community, moral values, moral education

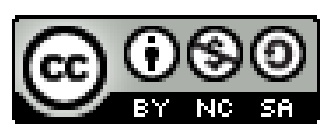

Cite in APA ${ }^{\text {th }}$

Rinenggo, A., \& Kusdarini, E. (2021). Moral values and methods of moral education at Samin community. Jurnal Civics: Media Kajian Kewarganegaraan, 18(1), 26-37. https://doi.org/10.21831/JC.V18I1.34580

\section{Introduction}

Carrying out of moral education is still dominant occur at a formal institution. Old people compete their children to school at formal institutions but should not control balance and moral education or character in family and social community. Asymmetry talked about being an able child have to deviate values in order to the social norm. For example less respectful, individualistic, and does not appreciate original cultural Indonesia. A non-formal institution such as a social community contributes to giving social control and conservation of cultural value. Appropriate by Laksono (2017, p. 111) said that "non-formal education has enormous potential to grow national democracy character".

Education is a substantial investment to improve human resources quality. Ballam et al., (2017, p. 5) states that "education is an interactive process and strategy for developing opportunity, aspiration, hope, and right for children, families, educators, communities, and the education system around the transition to school, along with the theories and beliefs constructing them". The main objective of education is to produce better people in all aspects of life, including moral, physical, social, vocational, aesthetic, intellectual, spiritual, and religious (Noddings, 2016).

The government's role in realizing the goals of national education has not been achieved well. Recently, the Indonesian nation's character has begun to be eroded by foreign cultures that are incompatible with the national personality. Jannah (2020) explains that a moral crisis occurs in children, adolescents, and adults. They do the behavior against the norms of decency and legal norms, for example, bullying, cheating, brawls, rape, murder, hate speech. Even criminal acts of corruption occur in all national lifelines and government institutions; for example, many legislators seize public money in the congregation, and selective law enforcement creates injustice in society. 
Sutrisno (2020) explains that several factors cause moral degradation in youth: technological development and progress, low faith, wrong relationship, low level of honesty, lost social responsibility, and lack of discipline. The moral degradation in the Indonesian nation has aroused collective awareness to re-strengthen the value of the nation's morality by optimizing its implementation through moral education. Efforts to strengthen society's character need to be carried out by moral education based on cultural values. Research conducted by Rohmatulloh et al., (2020, p. 1) shows that "character education through local value can maintain the cultural identity in Cirendeu traditional village by keeping adapting to current development".

Globalization can influence people's mindset and behavior through secularism, liberalism, radicalism, capitalism (Silitonga, 2020). Therefore, a person needs to develop the knowledge, attitude, and skill that will enable them to function in a global society. Educators worldwide need to be aware of and responsive to the dramatic changes towards the moral education needed in global education. The demands of moral education in the globalization era must be considered in any reform movement, both in school and society.

Moral education is a concept of goodness given or taught to students (youth and society) to form noble character and commendable behavior, as stated in Pancasila and the 1945 Constitution of the Republic of Indonesia (Darmadi, 2012). Moral education is not only run by the school, but it needs to involve society's role. Society functions to transfer value and control over each individual's attitude and behavior through mutually agreed on norms or became the local society's culture. Noddings (2010, p. 390) states that "moral education is traditionally carried out based on local society or religious norms". By involving the society in carrying out moral education, it is hoped that each society has a responsibility to protect, supervise and provide good direction in guiding attitude and behavior so they do not conflict with society's norms. Corson (2010) views community-based education as a form of social action within society's framework to be selforiented in creating a learning environment that is offered as a school.

Samin community is one of the indigenous people who have local wisdom values from their ancestral heritage. Currently, the Samin Community still exists in Klopoduwur Village, Banjarejo District, Blora Regency. The Samin community's existence has become a national cultural wealth with uniqueness and moral value preserved in family and society. In 2015, the Samin community in Blora received appreciation from President Jokowi. The President visited Klopoduwur Village directly and expressed his great pleasure to the Samin community's tradition of maintaining traditional culture. By the inclusion of foreign cultural values in the modernization era, it is precisely the moral teaching that upholds spiritual value, human value, and the value of preserving the natural environment that is still well actualized by the Samin community. This research aims to strengthen local culture-based values existing in the Samin community and civic education in the community that other researchers rarely study.

\section{Method}

This research was a qualitative approach with an ethnographic research type. The research was conducted in Klopoduwur Village, Banjarejo District, Blora Regency, from April 2019 to January 2020. The type of ethnographic research was used to understand and study the Samin indigenous community's moral values. The research subjects were determined by purposive sampling, including Samin traditional elders, Samin community members, and village apparatus. Collecting data techniques in this research were in-depth interviews, participatory observation, and 
documentation. An in-depth interview was used to explore Samin's moral values. The participatory observation was carried out to determine the method used by traditional elders in moral education for the Samin community. Meanwhile, documentation was carried out to see documents related to Samin's moral values and the Samin Community's activities. To valid the data, this research used source triangulation, and the technical triangulation technique. The data analysis technique used several stages. The first stage was preparing and organizing the data for analysis. The second stage is reading all the data. The third stage was coding data. The fourth stage was linking the theme/description. The last stage was interpreting the meaning of the theme/description. Data analysis used was inductive, meaning that data was explained from specific things to the general.

\section{Results and Discussion}

\section{Moral Values at Samin Community}

Samin community is an indigenous community formed caused conflicts during colonialism around the $19^{\text {th }}$ century where the Dutch government against Indonesian people. The arbitrariness committed by the Dutch government made a group of Samin community fight back by not paying taxes. Nowadays, the name of the Samin community is known as Sedulur Sikep. Sedulur sikep comes from the word 'Sedulur,' meaning brother. All human beings on earth are considered brothers because they were created by Gusti (God Almighty). In comparison, the term "Sikep" means rabi or married. The term "Sikep" is also interpreted as two meanings. For example, there are day and night, good and bad, male and female.

Samin Surosentiko is known to have died in Sawahlunto, Padang, but Samin's teaching is still being spread by his followers in Klopoduwur Village, Blora Regency. Samin's teaching was preserved by one of Samin Surosentiko's followers, Mbah Engkrek. Mbah Engkrek is known as Samin elder in Klopoduwur Village. Mbah Engkrek has the same role as Samin Surosentiko: to teach high moral value or procedures for behaving well with anyone. Since Mbah Engkrek died, Samin's moral teaching has been preserved by his descendant or great-grandson, namely Mbah Lasiyo as Samin elder in Klopoduwur Village.

Samin elders have an essential role in teaching the moral values of ancestral heritage to the Samin Community. The moral values inherited from the ancestors contain spiritual values, human values, environmental conservation values, and patriotism values. The samin community understands morality as teaching good behavior towards anyone because all are considered as brothers. Having a life principle adhering to good moral teaching and being practiced in society will create a mutual respect attitude and live in harmony and peace in society. Durkheim states that morality is always connected with society: morality is possible because of society, meaning that humans become moral beings because they live in a society (Ritzer \& Smart, 2012). Morality demands to be firm with ourselves and generous towards others and can help judge when people's judgment of others exceeds the limit (Watson \& Guidry-Grimes, 2018). The Samin Community's moral values are indirectly contained in the teachings of Panca Sesanti, Panca Wewaler, and Panca Peniten, which can be seen in table 1.

Table 1

Type of Moral Teaching and Moral Values at Samin Community

\begin{tabular}{lll}
\hline No. & Type of Moral Teaching & \multicolumn{1}{c}{ Moral Values } \\
\hline 1. & Panca Sesanti & Seduluran (brotherhood), ora seneng memungsuhan (do not \\
& & $\begin{array}{l}\text { like to be hostile / live in harmony), ora seneng rewang kang } \\
\text { dudu samestine (not taking sides / intermediary), ojo ngrenah }\end{array}$ \\
\hline
\end{tabular}




\begin{tabular}{|c|c|c|}
\hline & & $\begin{array}{l}\text { liyan (do not slander), eling Sing Kuwoso (remember God } \\
\text { Almighty). }\end{array}$ \\
\hline & Panca Wewaler & $\begin{array}{l}\text { Tresna pepadhane urip (loving other living beings), orak nerak } \\
\text { wewalerane negoro (does not violate state regulations), orak } \\
\text { nerak sing dudu sakmestine (not violating what is prohibited), } \\
\text { ora cidro ing janji (not breaking the promises), ora sepoto } \\
\text { nyepatani (not easy to swear). }\end{array}$ \\
\hline & Panca Peniten & $\begin{array}{l}\text { Becik ketitik ala ketoro (good will be proven and evil will be } \\
\text { seen), temen bakal tinemu (sure to succeed), ojo dumeh (do not } \\
\text { overdo), mok mek awake dhewe (just taking one's own), idi } \\
\text { pesthi weke Gusti (all belong to God). }\end{array}$ \\
\hline
\end{tabular}

Source: Elders of Samin in Klopoduwur Village

Panca Sesanti is five moral teachings relating to fellow humans, the relationship between humans and the universe, and the relationship between humans and God Almighty. This moral teaching contains five principles: firstly, seduluran (brotherhood). Living in this world must have many siblings because humans are social creatures who cannot be separated from others' help. By having many siblings wherever they are, they will feel comfortable, help each other, and share. This brotherhood is one of the central visions of the Samin community in building community life. The principle of the Samin community's brotherhood is that they must help each other in goodness in society. The following is Samin's brotherhood with the surrounding that can be seen in figure 1.

Figure 1

The Brotherhood of the Samin Community with the Surrounding Community

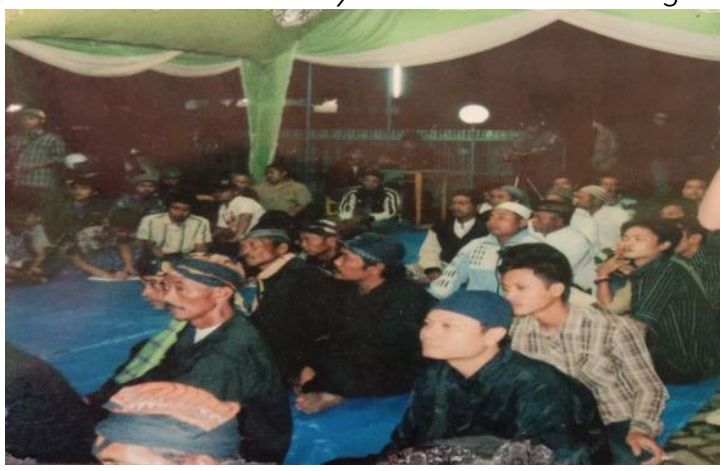

Source: Elders of Samin

Secondly, ora seneng memungsuhan/rukun (do not like to be hostile/live in harmony). Rukun is an attitude that promotes peace, unity, and peace in society. Each person has different beliefs and interests. If social life is not imbued with an attitude of harmony, the horizontal conflict will occur in society. The people in Klopoduwur Village's lives seem to be harmonious without conflict despite their different beliefs or religions. The Samin community's life principle is that they must build harmony regardless of religion or belief held by each individual. Thirdly, ora seneng rewang kang dudu samestine (not taking sides/intermediary). The Samin community has the belief that when problems occur in society, they should not defend one party because they can become enemies. They are trying to take a solution way to reduce the problems that occur in society. Fourthly, ojo ngrenah liyan (do not slander). Slandering is an attitude of accusing others without actual evidence. The Samin community avoids this kind of attitude because it can destroy friendships and brotherhood. Those despicable acts can play one person against another, causing enmity. Fifthly, eling Sing Kuwoso (remember God Almighty). Remembering God Almighty is a humans' obligation because God creates man, the universe and everything in it. God has given everything, from health, sustenance, long life and other happiness for humans. As a manifestation 
of these spiritual values, Samin Community always pray together every night of Selasa Kliwon and Jumat Kliwon.

Panca Wewaler means five moral teachings related to human life's rules in the association of society, nation and state. Firstly, tresna pepadhane urip (loving other living beings). Loving other living being is a human nature that is unconsciously owned by every human being typically. By loving and cherishing anyone, this life will automatically be peaceful, safe, and serene. One should not be arbitrary towards all living things in the universe. Secondly, orak nerak wewalerane negoro (does not violate state regulations). Obedience to state regulations is every society's obligation which must be implemented to fulfill common interests. Recently, the Samin community always obey state regulations, such as paying building tax, making ID cards, registering marriage at KUA, and attending primary and secondary education funded by the government. One form of obedience of the Samin community to the country is loyalty and love for Indonesia's Republic. The manifestation of the Samin community's attitude can be seen in raising the red and white flag in front of the house and the Samin Community Hall. Samin community is aware that commemorating the Indonesian Nation's Independence Day is a form of appreciation for the heroes' services died against the colonialists. Thirdly, orak nerak sing dudu sakmestine (not violating what is prohibited). The purpose of this moral value is compliance with the rules that have been agreed upon in society. These rules can be in the form of politeness and appropriateness related to society's good culture that society must obey. Fourthly, ora cidro ing janji (not breaking the promises). A promise is like a debt that must be paid. When someone has a promise to anyone it must be fulfilled or kept to avoid making disappoint to others. Breaking a promise that has been made will cause disharmony in friendship and kinship, even in a society that caused chaos. Fifthly, ora sepoto nyepatani (not easy to swear). The Samin community believes that taking an oath is forbidden because it is closely related to the Creator. Humans are sometimes wrong and negligent in their attitude and behavior, so they cannot swear on behalf of God Almighty.

Panca Peniten is five moral teachings that contain reminders for humans about something or the result that has been done. Firstly, becik ketitik ala ketoro. The meaning is that goodwill be proven, and evil will be seen. Secondly, temen bakal tinemu (sure to succeed). The meaning is if everyone always tries, works hard, and never gives up easily, one day he will find success. Hard work is the spirit of the Samin community in everyday life. Agriculture is the main basis of the Samin community. The spirit of working to meet daily needs is done by raising livestock and farming. Thirdly, ojo dumeh (do not overdo). This teaching reminds us that humans should not overdo anything that can lead to an arrogant attitude, for example, wealth, position, beauty or good looks, descent. Fourthly, mok mek awake dhewe (just taking one's own). This teaching contains honesty value. Honesty means saying something following reality, acting as it is, and not taking something that is not right. Taking ownership of others is a disgraceful act that can harm others. Fifthy, idi pesthi weke Gusti (all belong to God). It means that everything in the world belongs to God Almighty. Humans must realize if one day, everything can be taken at any time by His will. Material things, such as property, wealth, and position, owned by humans, are entrusted by God, which is impermanent in the world.

Morality has resulted from social interaction and incorporation in a group (Nucci et al., 2014, p. 186). However, Durkheim believes that moral development is a natural result of emotional attachment to the group, manifesting itself in respecting the group's symbols, rules, and authority, 
along with a spirit helping control behavior and channel. In contrast to Durkheim, Piaget points out that morality is not just a set of symbols, rules, and internalized norms. It characterizes children's moral development as a progressive construction of an increasingly solid and inclusive way of thinking about justice, equality, and respect for people.

The moral values inherited by Samin's ancestors are a beneficial virtue to humans, nature, society, and country. Lickona (2012) states that virtue is good for individuals because they must live a satisfying life in harmony with human beings. They are suitable for the entire human community allowing for harmonious and productive coexistence. Kohlberg argues that cognitive and moral development is the primary educational goal under Piaget and his theory. In line with Dewey, the educational process can be identified with the growth or development physically and intellectually, and morally (ísaksson, 2006, p. 59). The Samin community understands Samin's moral value as a form of education in a very important society because it can form a community's cultural identity reflecting a noble character. Blackford (2016) sees from an anthropological perspective and morality is a social phenomenon that can be studied. Therefore, it can be seen in a society that humans display a complex system of behavior norms, namely a system of rules and expectations that govern behavior, including expectations related to character disposition.

The moral values of the Samin Community could be used to a source of value in civic education. In summary, it could be categorized into five types, namely the morality of the relationship between humans and God Almighty, individual morality, human relations morality, human relationship morality with nature, and society-state morality. If these values of morality could be properly actualized in people's lives, a virtuous society would be created according to the values of Pancasila. Citizenship education that occurs in society is planned, implemented, developed, and assessed by the community to answer future-oriented challenges and opportunities (Aulia \& Arpannudin, 2019).

\section{Methods of Moral Education at Samin Community}

Moral education aims to foster morally depend on belief and action, skilled moral reasoning, morally regular habits, morally commendable moral trait, and character and expected moral sentiment" (de Ruyter \& Miedema, 2011, pp. 64-65). Moral formation requires a specific view of broader moral development. This view emphasizes that in a practice community, specific values and dispositions need to be shared and maintained by community members to develop (Reilly \& Stapleford, 2018).

The moral education carried out by Samin ancestors in society is a tradition that has been passed down from generation to generation. The purpose of moral education is to preserve the teaching of good behavior from the ancestors' legacy. Samin's moral teachings become a belief that is inspired and used as a life principle as the Samin people's identity who uphold noble moral values. Partly of them admit as adherent reliance although inside identity card sign inhabitant (KTP) Islam religion. Inclusion Islam religion in card sign inhabitant mentioned because presence duress from government era new sociopolitical or economic system.

Samin's moral values' internalization is carried out in three stages, such as understanding, appreciating, and practicing value. Firstly, understanding the moral value of Samin is done by direct orally conveyed by Samin elders. Samin elders explain that moral values which are inherited from our ancestors must be preserved. This understanding is carried in gathering every night on Selasa Kliwon and Jumat Kliwon. An important domain of moral value taught are related to human relationship (honesty, help, brotherhood, harmony, and tolerance), human relation with the natural environment (having ethic when planting and harvesting plants and protecting the 
environment), human relations with God YME (Have Faith and Piety), the relationship between society and the country (obey, love the country). Secondly, appreciating the value means that Samin's teaching followers feel the importance of the teaching value in their personal or social life in society. The Samin community believes that life will become wild and out of control if humans do not have moral value guidelines. Thirdly, practicing value means that the moral value that ancestors have passed down after being understood and lived, then indirectly practiced in everyday life.

The stages of actualizing Samin's moral value are following Lickona's view; a character is understood to have three interrelated parts: moral knowledge, moral feeling, and moral behavior (Lickona, 2009). A good character in Lickona's view includes knowledge of goodness (moral knowledge), then awakens commitment (intention) to be good (moral feeling) and then can do good that is called moral behavior (Sulasmono et al., 2017). In line with the opinion of Frisancho and Delgado (2018), that moral education contributes to the quality of society by enhancing the moral identity of its society, their ability to reason from an ethical point of view, and their capacity to take roles. Besides, responsibility, understood as an expression of personal freedom and attention to one's action and thought, is the goal of moral education (Bara \& Estrada, 2013). Moral education can help a person acquire a set of beliefs and values about what is right and wrong. This belief series directs their intention, attitude, and behavior towards others' environment and their environment (Clauss-Ehlers, 2010).

The moral education method is needed to simplify, explain, provide understanding, and instill moral value, so the goals to be achieved can be absorbed and entered into each individual's personality. The Samin elder uses several methods in teaching moral values to the community, which can be seen in table 2 .

Table 2

Methods of Moral Education at Samin Community

\begin{tabular}{|c|c|c|}
\hline No. & Methods of Moral Education & Statement \\
\hline 1 & Oral tradition & Doing by expression or spoken. \\
\hline 2 & Words of wisdom & $\begin{array}{l}\text { Words who have the imperative quality, } \\
\text { prohibition, and attentive. }\end{array}$ \\
\hline 3 & Habituation & $\begin{array}{l}\text { Routine activity by the manner group and pray } \\
\text { together every Tuesday Kliwon and Friday Kliwon. }\end{array}$ \\
\hline 4 & Role models & $\begin{array}{l}\text { Doing by good attitude and good behavior in } \\
\text { alive every day. }\end{array}$ \\
\hline 5 & Question and answer & $\begin{array}{l}\text { Question and answer related to Samin's } \\
\text { teachings. }\end{array}$ \\
\hline
\end{tabular}

Source: Researcher, 2020

Oral tradition is a method applied through speech or orally to teach moral value. Traditional elders conveyed Samin's moral value through speech to community members who adhere to Samin's teaching in Samin Community Hall. The place is used to transfer moral value to the Samin community. This is done by Samin elder because he could not write or read. Through this method, the moral value can be appropriately conveyed and can be understood by the Samin community (Sedulur Sikep). Through tradition, a community can convey oral history, oral literature, oral law, and other knowledge to future generation (Rahayuningtyas \& Jazuli, 2018, p. 324). Oral tradition is oral habit of the community in carrying out and inheriting custom considered as sacred thing (Turmuzi et al., 2018, p. 99). Oral tradition has been passed down from generation to generation 
in Klopoduwur Village since Mbah Engkrek as Mbah Lasiyo continued the Samin elder. Samin teaching, Panca Sesanti, Panca Wewaler, and Panca Peniten, is conveyed directly by Samin elders when they are gathering. After Samin teaching followers receive advice or direction regarding the moral value, it will indirectly be taught to each family member and practiced in everyday life. Oral tradition significantly influences how a person understands and interprets as an attempt to teach or pass on knowledge to the next generation through spoken or speech (RWD. et al., 2017)

Words of wisdom is an oral and written method that contains wise words to introduce and teach Samin's moral values. This paper contains behavioral teaching that is used as commandment, prohibition, and reminder. This Samin moral teaching is framed in the form of a figure installed in Samin elders' house and Samin Community Hall. Samin's writing of moral value aims to strengthen Samin's cultural identity and introduce Samin's teaching to others when visiting Klopoduwur Village. Words of wisdom are in the form of both written and unwritten, for examples:

Becik ketitik ala ketara (good will be proven, bad will be seen)

Temen bakal tinemu (keep trying, it will succeed)

Ojo dumeh (do not overdo)

Idi pesthi weke Gusti (all belong to God)

Ojo drengki-srei (do not be jealous and envious)

Watu, gunung, godhong, kekayon, kuthu-kuthu, walang atogho, kang ana sak lumahing bumi sak kureping langit pesasat sedulurku (Stones, mountains, leaves, wood, all plants, animals existing on earth and sky are all my brothers)

The meaning contained in the word of wisdom is to accommodate one's thought and understanding of the individual or social environment.

The habituation carried out by Samin elders, and Samin Community is seen from their routine activities every night of Selasa Kliwon and Jumat Kliwon. These two days are believed to be good days for gathering at Samin Community Hall in Klopoduwur Village. After the gathering is over, at midnight, it is continued by saying a prayer to God Almighty, so health, safety, sustenance, and peace in society are always rewarded. This recurring habit is considered a positive activity to inspire, live and practice Samin teaching. Harley (2017, p. 7) explains that "a person who is accustomed to taking action for the same reason as a virtuous agent even though he does not yet have a deep understanding, the repetition of these actions will be the basis for internal motivation because they are carried out for the same purpose, following virtue". Complete virtue and practical wisdom comprise the end of Aristotle's moral development, but wisdom cannot be cultivated directly through argument and teaching. Wisdom is integrated and built through habituation: the acquisition of virtuous character through repeated practice according to virtuous action (Sanderse, 2020, p. 1).

Samin elders' model is the role model of the attitude and behavior practiced in everyday life, such as maintaining good oral, having a simple appearance, establishing harmony in the community, being tolerant between religious communities or other beliefs, living in harmony, cooperating in community activities. Willemse et al., (2008, p. 462) conclude that moral education is very dependent on each teacher's personality. Modeling is an effective way to instill Samin's moral values in society. Samin traditional elders believe that he must be a role model or good practice to teach goodness value. In line with Bouas (2008) that teachers or instructors must be committed to modeling the type of self-control, they want in their students.

Society will see and realize that the attitude and behavior modeled indirectly will be imitated and practiced by the community. Someone is considered unkind if they just speak and command 
without acting or giving a direct model. This will backfire for those who command to practice moral values. According to Tse and Zhang (2017, p. 53), "role models that can be done by studying constructive behavior and morality by observing role models in a meaningful way to cultivate moral sensitivity". Providing a role model is also one of the fundamental moral education methods.

The last method is question and answer. Question and answer is a method used by traditional Samin elders with the Samin Community to conduct question and answer related to Samin's teachings. For example, ask about prayers for planting rice, harvesting rice, traveling, and Samin spirituality teachings. Question and answer is a teaching method in which there is direct two-way communication due to dialogue between teacher and students (Siregar, 2013). One of this method's goals is to provide an opportunity for someone to ask a question related to a problem that has not been understood.

\section{An Obstacle in Carrying Out of Moral Education at Samin Community}

The Samin community resides in a region separated from a government village with a distance of about $2 \mathrm{~km}$. The distance between one family and another is still separated. According to social structure, Samin Community only consists of old guided and Samin teaching participant. The Samin community believed that if they do not practice Samin's moral values in their daily lives, they will get sanctions from nature, such as obstacles, disaster, disease, and difficult livelihood. Moral education aims to create people's capacity to live under an ethical system and have resulted in humans watching norms and everyday regulation closely to not inflict a financial loss on other people's rightness and virtue that make social life (Engelen et al., 2018).

The moral education carried out by the Samin traditional elders get obstacle that is a negative stigma (stereotypes) from people outside the Samin group. Samin community, the famous as human as rebel, should not pay tax country, should not manage card sign inhabitant (KTP), language who has use reputed strange, and believed of attentive also different from the surface in the general community. Some of the attitudes shown were defiance carried out by Samin's ancestors during the Dutch colonial rule in Indonesia. The Samin community already a usual general community who are fair characteristic about everyone, send to school their children going to formal institute and loyal to country regulation.

Stereotypes highlight differences among groups and especially inaccurate (consisting of impossible and extreme types) when groups are similar (Bordalo et al., 2016). The negative assessment outside community towards the Samin Community is an accusation that is not based on facts but only an opinion that has already been negative from the historical chronology.

\section{Conclusion}

The Samin community has inherited moral values which can be categorized into three types: (1) Panca Sesanti, which includes: (brotherhood; harmony; mediation; no slander; remember God Almighty); (2) Panca Wewaler (loving fellow living beings, obeying the state, not violating what should be prohibited, not breaking promises, not easily swearing); (3) Panca Peniten, includes: becik ketitik ala ketara / something good will be proven, and wrong will be seen, temen bakal tinemu / people who are always trying to find success, ojo dumeh / should not overdo it in any way, mok mek awake dewe / just taking personal rights, idi pesthi weke Gusti / everything that belongs to God. The methods used by the Samin elders in carrying out moral education for the Samin Community are through oral traditions, wise words, habituation, role models, and question and answer. The elder of Samin's obstacle was that there was still a negative stigma from the outside community towards the Samin Community. Researchers suggest that the general public 
respects the Samin people's beliefs and continues to support the existence of local culture-based moral education as long as it does not conflict with Pancasila values.

Implication than research output such as moral education did by Samin community part form to civic education in context community. One grew up to value Samin culture if it is well preserved so identity and local ability could prevent Western culture that should not appropriate with nation Indonesia personality.

\section{Acknowledgment}

The authors say thanks to the Directorate of Research and Community Service Deputy for Research Streng Thening and Research Ministry Development and Technology / Research Body and National Innovation, the one who have financed master's thesis research funding appropriate contract research estimate year 2020 by number: 058/SP2H/LT/DRPM/2020.

\section{References}

Aulia, S. S., \& Arpannudin, I. (2019). Pendidikan kewarganegaraan dalam lingkup sosio-kultural pendidikan non-formal. Jurnal Civic Education: Media Kajian Pancasila dan Kewarganegaraan, 3(1), 1. https://doi.org/10.36412/ce.v3i1.902

Ballam, N., Perry, B., \& Garpelin, A. (2017). International perspectives on the pedagogies of educational transitions. In Pedagogies of educational transitions (Vol. 16, pp. 1-12). Springer. https://doi.org/10.1007/978-3-319-43118-5_1

Bara, F. E., \& Estrada, M. R. B. (2013). Why moral education is motivating by nature. In K. Heinrichs, F. Oser, \& T. Lovat (Eds.), Handbook of moral motivation: Theories, models, applications. Sense Publishers.

Blackford, R. (2016). The mystery of moral authority. Springer.

Bordalo, P., Coffman, K., Gennaioli, N., \& Shleifer, A. (2016). Stereotypes. The Quarterly Journal of Economics, 131(4), 1753-1794. https://doi.org/10.1093/qje/qjw029

Bouas, M. J. (2008). The three R's of moral education: Emile durkheim revisited. Educational Forum, 57(2), 180-185. https://doi.org/10.1080/00131729309335409

Clauss-Ehlers, C. S. (2010). Encyclopedia of cross-cultural school psychology. Springer US. https://doi.org/10.1007/978-0-387-71799-9

Corson, D. (2010). Community-based education for indigenous cultures. Language, Culture and Curriculum, 11(3), 238-249. https://doi.org/10.1080/07908319808666555

Darmadi, H. (2012). Dasar konsep pendidikan moral landasan konsep dasar dan implementasi. Alfabeta.

de Ruyter, D. J., \& Miedema, S. (2011). Moral education and development. Sense Publishers. https://doi.org/10.1007/978-94-6091-716-5

Engelen, B., Thomas, A., Archer, A., \& van de Ven, N. (2018). Exemplars and nudges: Combining two strategies for moral education. Journal of Moral Education, 47(3), 346-365. https://doi.org/10.1080/03057240.2017.1396966

Frisancho, S., \& Delgado, G. E. (2018). Moral education as intercultural moral education. Intercultural Education, 29(1), 18-39. https://doi.org/10.1080/14675986.2017.1405214

Harley, D. (2017). The goal of habituation in Aristotle: A Neo-Mechanical Account. 
ísaksson, A. (2006). Kohlberg's theory of moral development and its relevance to education. Scandinavian Journal of Educational Research, 23(2), 47-63. https://doi.org/10.1080/0031383790230202

Jannah, K. (2020). Merosotnya moral pemuda di era millennial. https://kabarmadura.id/merosotnya-moral-pemuda-di-era-millennial/

Laksono, B. A. (2017). Peran pendidikan nonformal dalam menumbuhkan karakter demokratis. Seminar Nasional Pendidikan, 111-119.

Lickona, T. (2009). Educating for character: How our schools can teach respect and responsibility. Bantam Books.

Lickona, T. (2012). Action in teacher education character education : Seven crucial issues. October 2014, 37-41. https://doi.org/10.1080/01626620.1999.10462937

Noddings, N. (2010). Moral education in an age of globalization. Educational Philosophy and Theory, 42(4), 390-396. https://doi.org/10.1111/j.1469-5812.200

Noddings, N. (2016). Moral life and education. Action in Teacher Education, 38(3), 212-216. https://doi.org/10.1080/01626620.2016.1194783

Nucci, L., Krettenauer, T., \& Narvaez, D. (Eds.). (2014). Handbook of moral and character education (2nd ed.). Routledge.

Rahayuningtyas, W., \& Jazuli, M. (2018). Oral tradition as a medium of inheriting dramatari wayang topeng in padepokan seni topeng Asmarabangun, Malang, Indonesia. The Journal of Educational Development, 6(3), 323-332. https://doi.org/10.15294/JED.V6I3.24285

Reilly, T. S., \& Stapleford, T. A. (2018). Science, virtue, and moral formation. Journal of Moral Education, 47(3), 267-271. https://doi.org/10.1080/03057240.2018.1484583

Ritzer, G., \& Smart, B. (2012). Handbook teori sosial. Nusa Media.

Rohmatulloh, R., Hasanah, A., \& Ruswandi, U. (2020). Character education of food local culture values in the people of Kampung Adat Cirendeu in West Java through exemplary. Jurnal Pendidikan Karakter, 10(1). https://doi.org/10.21831/jpk.v10i1.28658

RWD., F., Utama, N. J., \& Sinaga, R. (2017). The oral tradition as a source of learning the local history of South Sumatera. First Indonesian Communication Forum of Teacher Training and Education Faculty Leaders International Conference on Education, 496-499. https://doi.org/10.2991/ice-17.2018.105

Sanderse, W. (2020). Does Aristotle believe that habituation is only for children? Journal of Moral Education, 49(1), 98-110. https://doi.org/10.1080/03057240.2018.1497952

Silitonga, T. B. (2020). Tantangan globalisasi, peran negara, dan implikasinya terhadap aktualisasi nilai-nilai ideologi negara. Jurnal Civics: Media Kajian Kewarganegaraan, 17(1), 1528. https://doi.org/10.21831/jc.v17i1.29271

Siregar, E. A. (2013). Meningkatkan keterampilan bertanya dengan menggunakan metode tanya jawab pada mata pelajaran PKn siswa kelas IV SD. School Education Journal, 1(1), 103-112.

Sulasmono, P., Ekosiswoyo, R., Widodo, J., \& Sugiyo. (2017). The integration of local cultural wisdom values in building the character education of students. International Journal of Education and Research, 5(6), 151-162.

Sutrisno, S. (2020). Internalisasi pendidikan moral pada perguruan tinggi di Jepang. Jurnal Civics: Media Kajian Kewarganegaraan, 17(1), 50-59. https://doi.org/10.21831/jc.v17i1.30338 
Tse, T. K. C., \& Zhang, L. (2017). Changing mode of regulation: Role models in moral education textbooks for primary schools in China, 1999-2005. Frontiers of Education in China, 12(1), 52-74. https://doi.org/10.3868/s110-006-017-0004-2

Turmuzi, A., Emzir, E., \& Lustyantie, N. (2018). Moral values in oral tradition bekesah puspakrama at the Sasak Community in the West Nusa Tenggara (A structural and semiotic review). Advances in Language and Literary Studies, 9(3), 98-103. https://doi.org/10.7575/aiac.alls.v.9n.3p.98

Watson, J. C., \& Guidry-Grimes, L. K. (2018). Moral expertise: New essays from theoretical and clinical bioethics (Vol. 129). Springer.

Willemse, M., Lunenberg, M., \& Korthagen, F. (2008). The moral aspects of teacher educators' practices. Journal of Moral Education, 37(4), 445-466. https://doi.org/10.1080/03057240802399269 